\title{
Analysis of rainfed alfalfa evapotranspiration measured by an eddy covariance system
}

\author{
A. Vinci, L. Vergni, F. Todisco, F. Mannocchi \\ Department of Civil and Environmental Engineering, University of Perugia, Perugia, Italy
}

\begin{abstract}
The aim of this study was to quantify the evapotranspiration $\left(\mathrm{ET}_{\mathrm{ec}}\right)$ of a rainfed alfalfa crop using the eddy covariance technique. The study was carried out during the alfalfa growing seasons (AprilAugust 2009, April-August 2010) at the experimental farm of the University of Perugia. In central Italy alfalfa is grown for 3 to 4 years continuously, with at least 3 cutting cycles for year (usually between April and August) and a dormant period in winter. For the quantification of $\mathrm{ET}_{\mathrm{ec}}$ an open-path eddy covariance system (EC) was used. The derivation of water and energy fluxes starting from raw wind, temperature and gas concentration data by means of the EC technique implies a remarkably long sequence of operations including calibration, corrections and statistical tests for assessing data quality. These operations were carried out by the EddyPro® software. After that, the output data were used for the flux-partitioning and all original data, flagged with a quality indicator with non-turbulent conditions, were dismissed. Then the gap-filling of the EC and meteorological data was performed to obtain reliable values. Furthermore the test of the energy balance closure gave satisfactory results. The $\mathrm{ET}_{\mathrm{ec}}$ dynamics were consistent with the growth stages and the cuttings during both 2009 and 2010. Furthermore the comparison between the tabulated crop coefficients $\left(\mathrm{K}_{\mathrm{c}}\right)$ and the ratio of $\mathrm{ET}_{\mathrm{ec}}$ to reference evapotranspiration $\left(\mathrm{ET}_{0}\right)$ was performed. This analysis showed a good agreement during the $2^{\text {nd }}$ cutting cycle (May-June) for both 2009 and 2010, whilst during the $3^{\text {rd }}$ cutting cycle (July-August) the ratio $\mathrm{ET}_{\mathrm{e} d} / \mathrm{ET}_{0}$ was considerably lower than $\mathrm{K}_{\mathrm{c}}$ for both years. The reason of this behavior was found in the presence of water stress conditions during the last cutting cycle. This fact was confirmed by the application of a bucket soil water model, used as an exploratory, not confirmatory, tool to analyze the soil water availability dynamics during the growing season. Additional measurement campaigns will be carried out in order to deepen the knowledge about the $\mathrm{K}_{\mathrm{c}}$ dynamics
\end{abstract}

Correspondence: A. Vinci, Department of Civil and Environmental Engineering, University of Perugia, Borgo XX Giugno 74, 06121, Perugia, Italy. E-mail: avinci@unipg.it

Key words: crop coefficients, water stress, energy balance.

CCopyright A. Vinci et al., 2013

Licensee PAGEPress, Italy

Journal of Agricultural Engineering 2013; XLIV(s2):e157

doi:10.4081/jae.2013.s2.e157

This article is distributed under the terms of the Creative Commons Attribution Noncommercial License (by-nc 3.0) which permits any noncommercial use, distribution, and reproduction in any medium, provided the original author(s) and source are credited. in rainfed crops and to assess the productivity of water under various meteorological and agricultural conditions.

\section{Introduction}

As the water demand is projected to increase (Giorgi and Lionello, 2008), a correct and detailed quantification of crop water use by evapotranspiration (ET) in different climatic and agronomical conditions is necessary to improve water use efficiency for both irrigated and rainfed crops (Smith, 2000; Parent and Anctil, 2012).

ET can be measured or modeled by several techniques. For practical purposes, ET is usually estimated by models having minimal requirement of meteorological data. The technique best known and most used is the one based on the FA0-56 approach (Allen et al., 1998), according to which the potential evapotranspiration of a specific crop $\left(\mathrm{ET}_{\mathrm{c}}\right)$ is estimated through the combination of reference evapotranspiration $\left(\mathrm{ET}_{0}\right)$ and crop coefficients $\left(\mathrm{K}_{\mathrm{c}}\right)$. If some stress factor occurs (e.g. water stress) it is necessary to adjust the $\mathrm{ET}_{\mathrm{c}}$ value, by introducing a stress coefficient $K_{s}$.

Direct methods to measure ET (such as lysimetry and micrometeorology) are more complex and demanding. The micrometeorological methods measure the components of the energy balance which allows to accurately estimate ET from large areas even at short time scales (Baldocchi, 2003). These are typically research methods, due both to the complex data processing and to the expensive instruments required, but they are very useful to improve the knowledge about evapotranspiration and $\mathrm{K}_{\mathrm{c}}$ values.

A widely known micrometeorological method is eddy covariance. It is considered a direct and accurate method for measurements of both latent heat (ET) and sensible heat (H) fluxes (Stull, 1988; Rana and Katerji, 2000). The main idea of the eddy covariance method is to measure the turbulent transport of heat and water vapor in the vertical direction (Garratt, 1992; Campbell and Norman, 1998). The performance of the eddy covariance method is very good in hourly and daily time scales if sensors are placed in an appropriate geometrical configuration and special data corrections are made (Allen et al., 2011a,b; Foken et al., 2011a,b; Foken, 2008; Foken et al., 2004; Twine et al., 2000).

In this paper the eddy covariance method was applied in the monitoring of rainfed alfalfa evapotranspiration in Central Italy during two successive growing seasons (2009 and 2010).

Alfalfa (Medicago sativa L.) is one of the most grown forage crops in the Mediterranean where it plays an important economical and ecological role. In Central Italy it is a rainfed crop, grown for 3 to 4 years continuously, with 3-4 cutting cycles for year (usually between April and August) and a dormant period in winter.

The main objective of the paper was to derive actual crop coefficients $\left(\mathrm{K}_{\mathrm{c} \_ \text {act }}\right)$ for rainfed alfalfa and to analyze their response to climatic factors and agricultural management. Indeed, alfalfa crop coefficients are largely documented in literature (Allen et al., 1998; 
Doorenbos and Pruitt, 1977), but they are mainly related to irrigated crops.

\section{Materials and Methods}

\section{Experimental site, alfalfa data and instrumentation}

The study was carried out at one site located in Central Italy (Deruta, Perugia) during the years 2009 and 2010. Measurements of energy balance terms were made with an open path eddy covariance (EC) system. The EC system was installed in the middle of a 20.63 ha ( $42^{\circ} 57^{\prime} 2.31^{\prime \prime}$ $\mathrm{N}, 12^{\circ} 22$ ' 53.73 " E, $220 \mathrm{~m}$ a.s.l.) alfalfa farmland in both years. In this area, as already mentioned, alfalfa is grown for 3 to 4 years continuously after planting. The two years of experimentation corresponded to the $3^{\text {rd }}$ and the $4^{\text {th }}$ growing seasons respectively. The monitoring of evapotranspiration has been performed during the active growing season (from April to August). Each growing season was characterized by a series of three cutting cycles described by the sequence of four growth stages (Allen et al., 1998): initial (IS), crop development (DS), mid-season (MS) and late (LS). The actual lengths of different stages and the cutting dates were dependent on the weather conditions and on the farm management. The beginning and the end of the growth stages were identified according to the guidelines provided by Allen et al. (1998) together with the monitoring of alfalfa phenological development. The MS and LS stages are considered as a whole in the paper, because the LS stage was frequently interrupted by the cuttings and alfalfa crop coefficients are not much variable in the two stages.

Results only refer to the second and third cutting cycles of each season, since the first cycle (after dormancy) is characterized by the considerable presence of other species.

In the EC system there are two types of platforms: a fast-response and a slow-response system. The first measures the variables needed to compute the sensible and latent heat flux and consists of a 3D sonic anemometer/thermometer (model CSAT3) and a Li-7500 $\mathrm{CO}_{2}-\mathrm{H}_{2} \mathrm{O}$ infrared gas analyzer. CSAT3 and Li-7500 measure three-dimensional fluctuations of wind, sonic temperature, and concentrations of $\mathrm{H}_{2} \mathrm{O}$ and $\mathrm{CO}_{2}$ at $20 \mathrm{~Hz}$. These fast-response instruments were installed on a horizontal bar placed at the top of a tripod $1.7 \mathrm{~m}$ above the ground. The lateral separation between the two sensors was set at about $0.20 \mathrm{~m}$. The slow-response system consists of a net radiometer, four heat flux plates (Hukseflux HFP01SC) and two soil temperature sensors for two level soil measurements ( 0.10 and $0.15 \mathrm{~m}$ depth). In the year 2010 a multidepth soil water monitoring probe (EnviroSMART) was installed $(0.30$, $0.45,0.60 \mathrm{~m}$ ) and the Li-7500 was recalibrated. Checking and cleaning operations of the instruments were done weekly in correspondence of data download.

These instruments made it possible to measure independently the latent heat flux ( ET), sensible heat flux (H), soil heat flux (G) and net radiation $(\mathrm{Rn})$ in order to check energy balance closure. All the sensors were connected to a datalogger (model CR3000) and the 10-min statistics (average, variance and covariance) were computed.

Analysis of soil hydro-physical properties were carried out in the year 2010. In particular soil texture, water retention at field capacity and wilting point were determined at six depth up to $1.8 \mathrm{~m}$. The available water content (AWC) between field capacity and wilting point is about $12 \%$ with a low variability among the different layers.

\section{Eddy covariance measurements}

$\mathrm{H}$ and ET were measured: during the year 2009 between May 9 and May 30 (corresponding to the first 22 days of the $2^{\text {nd }}$ cutting cycle) and between July 9 and August 21 including the entire $3^{\text {rd }}$ cutting cycle and the initial period of the successive regrowth,; during the year 2010 between May 24 and August 3, including completely the $2^{\text {nd }}$ and $3^{\text {rd }}$ cutting cycles.

$\mathrm{H}$ and ET are given in units of power per unit of area $\left[\mathrm{Wm}^{-2}\right]$, and they were calculated using the eddy covariance system (Baldocchi, 2003):

$$
\begin{aligned}
& \lambda E T=\rho_{a} \lambda \overline{w^{\prime} q^{\prime}} \\
& \mathrm{H}=c_{p} \rho_{a} \overline{w^{\prime} T^{\prime}}
\end{aligned}
$$

where $\overline{w^{\prime} q^{\prime}}$ is the covariance between fluctuations of vertical wind speed $w^{\prime}\left[\mathrm{m} \mathrm{s}^{-1}\right.$ ] and humidity $q^{\prime}\left[\mathrm{kg} \mathrm{kg}^{-1}\right], \overline{w^{\prime} T^{\prime}}$ is the covariance between fluctuations of $w^{\prime}$ and sonic temperature $T^{\prime}[\mathrm{K}]$, a is the air density $\left[\mathrm{kg} \mathrm{m}^{-3}\right], \mathrm{c}_{\mathrm{p}}$ is the specific heat of dry air at constant pressure $\left[\mathrm{J} \mathrm{kg}^{-1} \mathrm{~K}^{-1}\right], \lambda$ is the latent heat of water vaporization $\left[\mathrm{MJ} \mathrm{kg}{ }^{-1}\right]$ and ET is the crop evapotranspiration $\left[\mathrm{kg} \mathrm{m}^{-2} \mathrm{~s}^{-1}\right]$. The ratio of ET to $\lambda$ enabled to obtain the measure of actual evapotranspiration $\mathrm{ET}_{\mathrm{ec}}$.

\section{EC data processing and gap filling}

The EC technique requires a considerable quality control process in order to obtain reliable measurements (Foken and Wichura, 1996).

For these reasons the EddyPro® software (open source) was used for processing raw eddy covariance data. EddyPro® allows calculating corrected fluxes starting from raw files through a long sequence of operations including filtering, calibration and other algorithms that user can configure to suit the research needs. In this study, the Advanced Mode was used for processing raw data and in particular: double axis rotation for tilt corrections of wind speed measurements, the block average detrend method for the corrections of the turbulent fluctuations and the covariance maximization for time lag compensation. Then, for the compensation of density fluctuations (WPL terms) an a posteriori correction (Webb et al., 1980) was applied. It adjusts density fluctuations using measured sensible heat and evapotranspiration fluxes, corrected for spectral losses and water vapor effects. Furthermore the Fast Fourier Transform (FFT) was used for the frequency domain analysis (spectra and co-spectra) of the time series data. Finally a quality check (Mauder et al., 2008) and a footprint estimation (Kljun et al., 2004) were implemented. Flux crosswind-integrated footprints were provided as distances from the tower contributing $10 \%, 30 \%, 50 \%, 70 \%$ and $90 \%$ to measured fluxes. In particular the location of the peak contribution were $278.5 \mathrm{~m}$ and $75 \mathrm{~m}$ (90\%), $67 \mathrm{~m}$ and $31 \mathrm{~m}$ (70\%), $33 \mathrm{~m}$ and $19.43 \mathrm{~m}$ (50\%) for 2009 and 2010 respectively.

Then the gap filling was applied to the EddyPro® output data. In particular, a tool that implements the standardized methods described in Reichstein et al. (2005) for processing half-hourly eddy covariance data (gap-filling and flux-partitioning) was used to replace the missing data. The missing value was replaced by the average value under similar meteorological conditions within a time-window of 7 days (because only the data of direct interest are missing, while all meteorological data are available). The similar meteorological conditions are present when the global radiation, the air temperature and the vapor pressure deficit do not deviate by more than $50 \mathrm{Wm}^{-2}, 2.5^{\circ} \mathrm{C}$, and $5.0 \mathrm{hPa}$ respectively. In the period June 1 - July 92009 the gap filling was not applied because in such long time-span there is a significant variation of crop characteristics that the method cannot consider. Furthermore the original data (not gap-filled) were used for the flux-partitioning..

\section{Energy balance closure test}

The plausibility of the datasets was valuated against the energy balance closure test (Farahani et al., 2007). The slope of regression 
between the energy measured by EC $(\mathrm{H}+\mathrm{ET})$ and the available energy $(\mathrm{Rn}-\mathrm{G})$ indicates the degree of energy balance closure, which should be close to 1 .

\section{Reference ET (ETo) and crop coefficients}

Daily reference evapotranspiration was calculated by the FAO Penman-Monteith equation (Allen et al., 1998). The daily agrometeorological data required by this equation and daily precipitation (for the soil water balance) were obtained from the closest meteorological station, about $600 \mathrm{~m}$ far from the considered alfalfa field.

Daily values of the actual crop coefficient $K_{c_{\_} \text {act }}$ were calculated as the ratio of $\mathrm{ET}_{\mathrm{ec}}$ to $\mathrm{ET}_{0}$.

$$
K_{c_{-} a c t}=\frac{E T_{e c}}{E T_{0}}
$$

$\mathrm{K}_{\text {__act }}$ is conceptually and numerically different from crop coefficients $\left(\mathrm{K}_{c}\right)$ usually available in literature. In fact $\mathrm{K}_{\mathrm{c}}$ are used to quantify the crop evapotranspiration $\left(\mathrm{ET}_{\mathrm{c}}\right.$ ) under the hypothesis of optimal environmental conditions with particular regard to water availability (i.e. under irrigation). The $\mathrm{K}_{\mathrm{c} \_ \text {act }}$ coefficient refers instead to crops that could have suffered water shortage conditions and for which evapotranspiration could have been lower than $\mathrm{ET}_{\mathrm{c}}$ for all or part of the growing season.

In this paper the tabulated Kc coefficients of Allen et al. (1998) have been considered as a term of comparison of $K_{c \text { act }}$, taking into account the conceptual differences discussed above. The alfalfa $K_{c}$ values given in Table 1 derive from Allen et al. (1998) after the adjustments proposed by the same authors for specific climatic and management conditions.

\section{Soil water balance}

A rough estimation of the alfalfa water availability was obtained by applying the following simplified water balance equation (Doorenbos and Kassam, 1986)

$$
P-E T_{e c}-D=\Delta S W
$$

where $\mathrm{P}$ is the measured precipitation, $\mathrm{ET}_{\mathrm{ec}}$ is the actual evapotranspiration (measured by eddy covariance), $\mathrm{D}$ is the deep percolation and DSW the water storage variation in a 0-2 $\mathrm{m}$ soil depth. This soil layer was assumed as the effective root-zone depth $(\mathrm{H})$ for alfalfa in the examined environmental conditions, considering the presence of a deep alluvial soil and the fact that at the $3^{\text {rd }}$ and $4^{\text {th }}$ year after seeding, alfalfa is well-established.

The drainage was quantified as the volume of water exceeding the maximum storage capacity of the soil, TAW=(AWC) $\cdot \mathrm{H}$.

In the water balance, surface runoff and capillary raise were both neglected due to the flat terrain conditions and to the deep groundwater table.

The soil water balance equation was applied in 2010 to estimate the soil water variation at a daily time scale $\left(\mathrm{SW}_{\mathrm{t}}\right)$, assuming an initial condition (on May 24) equal to TAW (reliable hypothesis taking into con-

Table 1. Alfalfa crop coefficients (Allen et al., 1998) for different growth stages under the specific climatic conditions of the case study.

\begin{tabular}{lc} 
Growth stage & Crop coefficient \\
Initial (IS) & $\mathrm{K}_{\mathrm{c} \text {-ini }}=0.40$ \\
Development (DS) & Linear variation between Kc-ini and Kc-mid \\
\hline Mid season (MS) & $\mathrm{K}_{\mathrm{c} \text {-mid }}=1.15$ \\
Late season (LS) & Linear variation between $\mathrm{Kc}$-mid and $\mathrm{K}_{\mathrm{c} \text {-end }}=1.08$ \\
\hline
\end{tabular}

sideration the abundant rainfall of April (66 mm) and May 2010 (108 $\mathrm{mm}$ ), the relatively small evapotranspiration rate until the first cut and the information obtained from the water content probe.

At any rate, this simplified method can have several inaccuracies: uncertainty about the actual alfalfa rooting depth, the assumption of spatial uniformity of soil characteristics, soil rootzone assumed as a reservoir etc.

\section{Results}

\section{Meteorological conditions}

The growing season 2009 was characterized by lower than average rainfall amounts in April, May and July, and higher in June and August . Mean air temperature was usually higher than average with the exception of June (probably due to the high rainfall). The growing season 2010 was characterized by lower or near normal rainfall amounts in all months with the exception of May (much-above average rainfall). The mean air temperature was lower than average in most months.

These climatic conditions can be considered advantageous for a good growth and yield of rainfed alfalfa in both years, even if the rainfall occurrence led often to non-optimal choices with regards to cuts scheduling.

\section{Energy balance closure test}

Figure 1 shows mean daily values of Rn-G vs. H+ ET obtained from both years. The slope of the linear fit of Rn-G vs. H+ ET is 0.89 . This little underestimation of the turbulent fluxes (by 11\%) can be considered acceptable (Foken, 2008), and it may depends on non ideal conditions (a not completely flat field, the inhomogeneity of the crop).

\section{Evapotranspiration by eddy covariance $\left(\mathrm{ET}_{\mathrm{ec}}\right)$ and actual crop coefficients $\left(K_{c_{-} \text {act }}\right)$}

The seasonal variation of daily $\mathrm{ET}_{\mathrm{ec}}$ and of the 3-day means of $\mathrm{K}_{\mathrm{c} \_a c t}$ are shown in figures

$2 \mathrm{~A}$ and $2 \mathrm{~B}$, respectively. The same information for 2010 is given in figures $3 \mathrm{~A}$ and $3 \mathrm{~B}$. Other variables and information, such as daily rainfall, $\mathrm{ET}_{0}$, growth stages length, cutting dates, $\mathrm{K}_{\mathrm{c}}$ (Allen et al., 1998), are

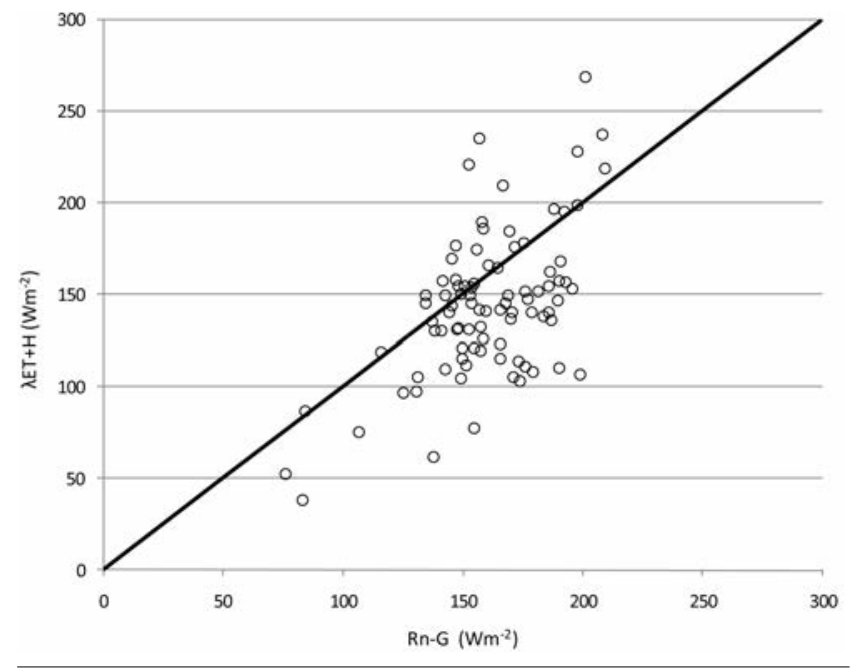

Figure 1. Daily energy balance of the turbulent flux $\lambda \mathrm{ET}+\mathrm{H}$ and the available energy Rn-G, and 1:1 line. Data from 2009 and 2010 . 
shown in the same figures. Summary statistics of daily values of $\mathrm{ET}_{\mathrm{ec}}$, $\mathrm{ET}_{0}$ and $\mathrm{K}_{\mathrm{c} \_ \text {act }}$ are shown in Table 2. Results are discussed separately for the year 2009 and 2010 in the next sections.

\section{Growing season 2009}

In 2009, $\mathrm{ET}_{\text {ec }}$ was first measured between May 8 and May 29, date on which data collection was suspended due to technical problems. During this cutting cycle (Figure 2A), the dynamics of $\mathrm{ET}_{\mathrm{ec}}$ is consistent with that expected during the observed growth stages: in fact $\mathrm{ET}_{\mathrm{ec}}$ shows a steady behavior after the cutting date (IS stage) and then a rapid increment during the following DS stage. The observation of this stage is not complete, but $\mathrm{ET}_{\mathrm{ec}}$ during the last days is very close to $\mathrm{ET}_{0}$, so that it can be assumed that during this cutting cycle almost optimal conditions occurred. This is confirmed by the dynamics of $\mathrm{K}_{\mathrm{c}_{-} \text {act }}$ (Figure $2 \mathrm{~B}$ ) that is aligned with that expected under optimal conditions $\left(\mathrm{K}_{\mathrm{c}}\right)$. During the stage IS, the mean $\mathrm{K}_{\mathrm{c} \_ \text {act }}$ is slightly lower than the $\mathrm{K}_{\mathrm{c}}$ expected under optimal conditions (Table 2).

Data collection in 2009 restarted after the second cut (July 9), with- out interruptions until the last cut on August 18. For few days after cutting (Figure 2A), ETec is almost stationary, then it shows a rapid increment during the development stage (until July 25) with final values of about $6 \mathrm{~mm} /$ day (compared to ET0 of about $7 \mathrm{~mm} /$ day). During the next MS-LS stages ETec shows a decreasing trend until the beginning of August when it increases to values of about $6 \mathrm{~mm} /$ day. After, ETec shows again a decreasing trend until the final cutting. The observed dynamics of ETec can be likely attributable to the presence of non-optimal conditions (in particular water shortage). The dynamics of Kc_act compared to that of Kc (Figure 2B) clearly demonstrates this situation: a part from the slight difference during the stage IS (Figure 2B and Table 2), then Kc_act and Kc follow the same dynamics until about July 14. After this date, Kc_act continues to increase at a slower rate for some days, then it shows an evident decrease until the end of July. The abundant rainfalls of August 2 and 3 (Figures 2A and B) determine a temporary recovery of both ETec and Kc_act, but the consistent evapotranspirative demand of the period leads to a rapid decreasing of both variables until the end of the cutting cycle.
A

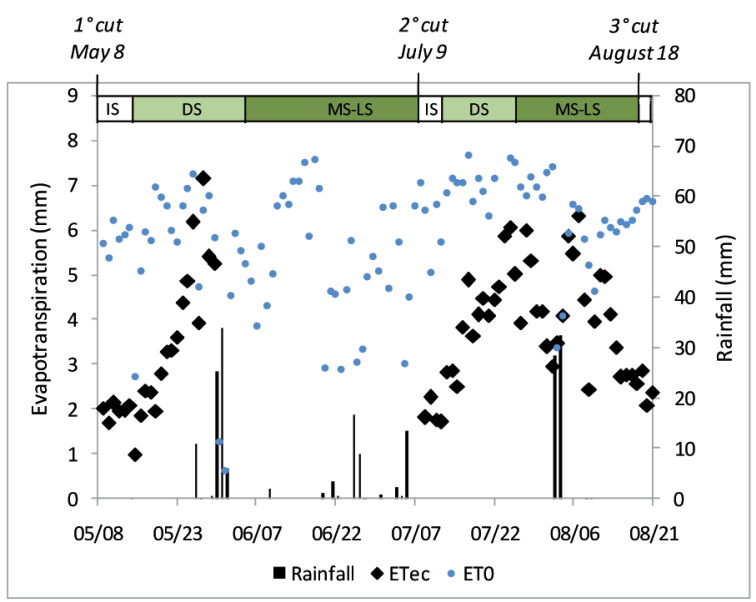

B

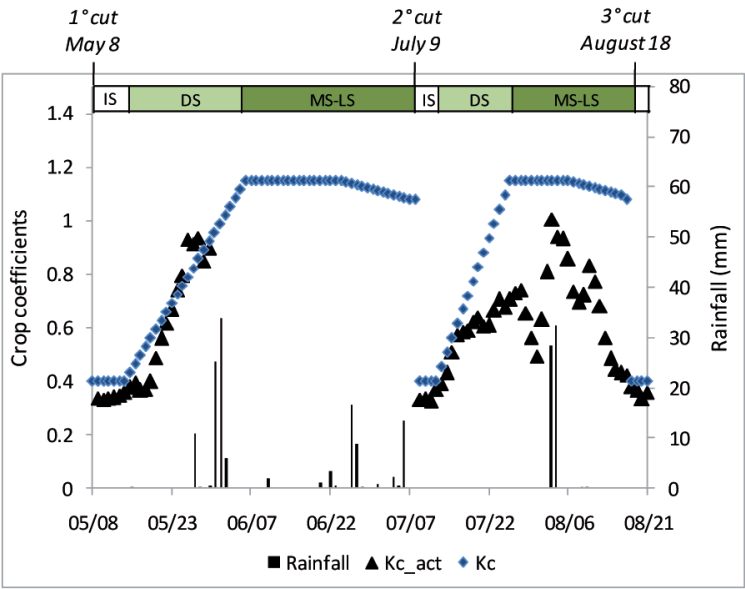

Figure 2. Daily values of rainfall, actual evapotranspiration measured by eddy covariance $\mathrm{ET}_{\mathrm{ec}}$, reference evapotranspiration $\mathrm{ET}_{0}$ in 2009 (A). Daily values of rainfall, 3-day means of $\mathrm{K}_{\mathrm{c} \_ \text {act }}\left(\mathrm{ET}_{\mathrm{ec}} / \mathrm{ET}_{0}\right)$ and daily crop coefficients, $\mathrm{K}_{\mathrm{c}}$, by Allen et al. (1998) in 2009 (B). IS, initial stage; DS, development stage; MS-LS, mid and late season stages.

Table 2. Statistics of daily evapotranspiration measured by eddy covariance $\left(\mathbf{E T}_{\mathrm{ec}}\right)$, reference evapotranspiration $\left(\mathrm{ET}_{0}\right)$, actual crop coefficients $\left(\mathrm{K}_{\mathrm{c} \_ \text {act }}\right)$ in 2009 and 2010 during alfalfa growth stages.

\begin{tabular}{|c|c|c|c|c|c|c|c|c|c|}
\hline \multirow[t]{2}{*}{ Year } & \multirow[t]{2}{*}{ Growth stage } & \multirow[t]{2}{*}{ Period } & \multicolumn{2}{|c|}{$\begin{array}{c}\mathrm{ET}_{\mathrm{ec}} \\
(\mathrm{mm} / \mathrm{day})\end{array}$} & \multicolumn{2}{|c|}{$\begin{array}{c}\text { ET }_{0} \\
\text { (mm/day) }\end{array}$} & \multicolumn{3}{|c|}{$\mathrm{K}_{\mathrm{c} \_ \text {act }}$} \\
\hline & & & Mean & Cumulated & Mean & Cumulated & Mean & Min & Max \\
\hline \multirow[t]{6}{*}{2009} & IS & 8-14 May & 1.98 & 11.90 & 5.85 & 35.10 & 0.34 & 0.31 & 0.35 \\
\hline & DS* & 15 May- 6 June & 3.73 & 59.80 & 6.00 & 96.00 & 0.61 & 0.28 & 1.11 \\
\hline & MS-LS ${ }^{\circ}$ & 7 June-8 July & - & - & 5.40 & 172.73 & - & - & - \\
\hline & IS & 9-12 July & 1.85 & 7.57 & 5.95 & 23.80 & 0.32 & 0.27 & 0.45 \\
\hline & DS & 13-25 July & 4.18 & 54.37 & 7.32 & 95.00 & 0.57 & 0.36 & 0.80 \\
\hline & MS-LS & 26 July-17 August & 4.20 & 96.78 & 6.16 & 141.65 & 0.70 & 0.40 & 1.03 \\
\hline \multirow[t]{6}{*}{2010} & IS & 24-28 May & 2.20 & 10.90 & 4.88 & 24.41 & 0.45 & 0.42 & 0.53 \\
\hline & DS & 29 May-12 June & 3.38 & 50.76 & 5.06 & 75.92 & 0.66 & 0.39 & 0.90 \\
\hline & MS-LS & 13-28 June & 4.28 & 68.50 & 4.80 & 76.75 & 0.87 & 0.68 & 1.10 \\
\hline & IS & 29 June-3 July & 2.22 & 11.10 & 6.51 & 32.56 & 0.34 & 0.23 & 0.47 \\
\hline & DS & 4 July-18 July & 2.93 & 44.05 & 6.42 & 96.24 & 0.45 & 0.28 & 0.60 \\
\hline & MS-LS & 19 July-1 August & 2.68 & 37.51 & 5.81 & 81.38 & 0.48 & 0.24 & 1.06 \\
\hline
\end{tabular}

IS, Initial stage; DS, development stage; MS-LS, mid and late season stages; * This stage has been observed until May 30 ; $^{\circ}$ This stage was not observed due to technical problems. 
A

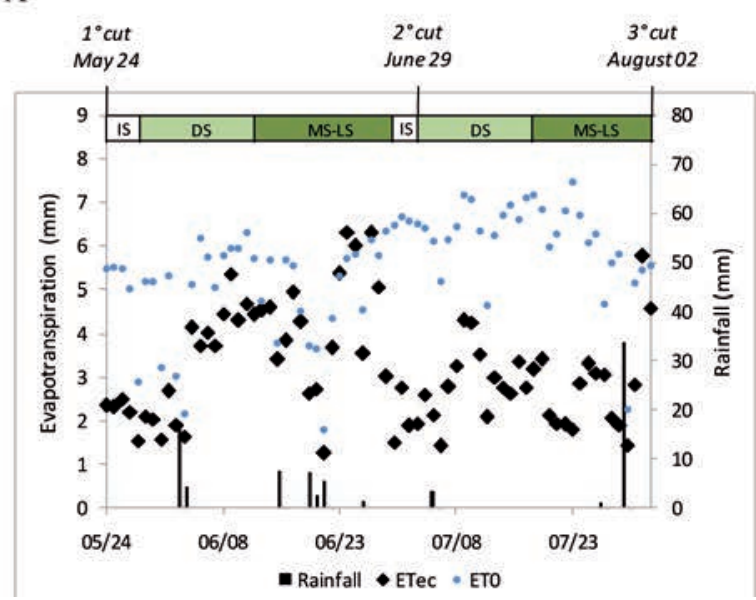

B

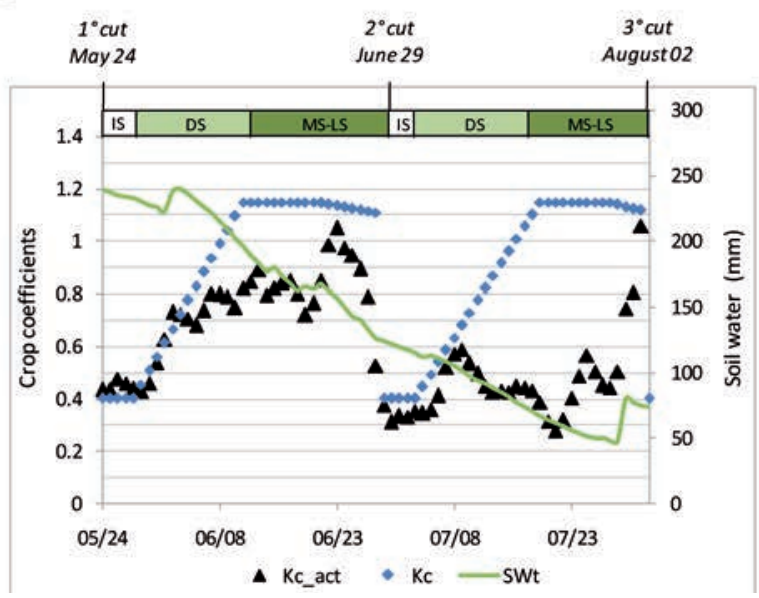

Figure 3. Daily values of rainfall, actual evapotranspiration measured by eddy covariance ET $_{\text {ec }}$, reference evapotranspiration ET $_{0}$ in 2010 (A). 3-day means of $\mathrm{K}_{\mathrm{c}_{-} \text {act }}\left(\mathrm{ET}_{\mathrm{ec}} / \mathrm{ET}_{0}\right)$, daily crop coefficients, $\mathrm{K}_{\mathrm{c}}$ (Allen et al.,1998) and simulated soil water dynamics (SWt) in 2010 (B). IS, initial stage; DS, development stage; MS-LS, mid and late season stages.

\section{Growing season 2010}

In $2010 \mathrm{ET}_{\mathrm{ec}}$ was monitored between May 24 and August 2 (Figure $3 \mathrm{~A})$, including two complete cutting cycles. A preliminary comparison between 2009 and 2010 (Figure 2A and 3A respectively) shows that in $2010 \mathrm{ET}_{\text {ec }}$ has a weaker relationship with growth stages. During the first monitored cutting cycle (May 24- June 29) $\mathrm{ET}_{\mathrm{ec}}$ shows a increasing tendency until June 20, followed by few days with very low values, after which $\mathrm{ET}_{\mathrm{ec}}$ rises to about $6 \mathrm{~mm} /$ day in the proximity of the cutting (Figure $3 \mathrm{~A}$ ). The $\mathrm{ET}_{\mathrm{ec}}$ drop after June 20 can be partially explained by the corresponding reduction of $\mathrm{ET}_{0}$ (Figure $3 \mathrm{~A}$ ) in correspondence of some cold and rainy days. The analysis of the $\mathrm{K}_{\mathrm{c} \_ \text {act }}$ dynamics, compared to $K_{c}$ (Figure $3 B$ ) depicts a probable condition of water stress after the first week of June, partially reduced by some rainfall events and by the $\mathrm{ET}_{0}$ reduction around June 20.

During the second monitored cutting cycle of 2010 (June 29 - August 2) low values for both $\mathrm{ET}_{\text {ec }}$ and $\mathrm{K}_{\mathrm{c} \_ \text {act }}$ (Figure $3 \mathrm{~A}$ and $\mathrm{B}$, Table 2) were recorded. In particular, the $K_{c \_ \text {act }}$ dynamics can be considered aligned (although lower) with that of $\mathrm{K}_{\mathrm{c}}$ only during the IS stage and during the first week of the DS stage. During the rest of the cycle, until the rainfall event of July $30(34 \mathrm{~mm}), \mathrm{K}_{\mathrm{C}_{\_} \text {act }}$ is always lower than 0.6 reaching a minimum of 0.24 on July 23. Both $\mathrm{ET}_{\mathrm{ec}}$ and $\mathrm{K}_{\mathrm{c} \text { act }}$ increase after the considerable rainfall event of July 30 , confirming that the low evapotranspiration during this cycle has been mainly dependent on water shortage.

Figure 3B shows also the dynamics of the simulated soil water availability SWt in 2010. This information confirms the presence of a relevant water shortage during the last cutting cycle. On the other hand, the SWt computed from the single-layer soil water balance can just provide general information and it is not well correlated with short-term variations of $\mathrm{K}_{\mathrm{c} \_ \text {act }}$ and actual ET (e.g. the brief $\mathrm{K}_{\mathrm{c}_{\_} \text {act }}$ recovery on June 20 and July 30 , due to rainfall events).

\section{Conclusions and discussion}

The paper shows an analysis of rainfed alfalfa evapotranspiration, measured by eddy covariance technique. The main objective was to obtain a precise evaluation of actual crop coefficients of rainfed alfalfa and their response to climatic factors and agricultural management. The tabulated crop coefficients for optimal conditions were used as term of comparison. The main results can be summarized as follows:

in most cases, the $\mathrm{K}_{\mathrm{c} \_ \text {act }}$ during the days following the cutting was slightly lower than the tabulated $\mathrm{K}_{\mathrm{c}}$ value (Allen et al., 1998) for the same stage $\left(\mathrm{K}_{\mathrm{c}_{\_} \mathrm{ini}}\right)$. Since ET in this phase is mainly ruled by the evaporation process, the detected differences were unlikely dependent on crop water shortage. Local conditions (cutting height, crop density, wetting/drying cycles) are the most probable influencing factors of actual ET in this stage that can be adequately described only by a direct measurement (like EC).

during the DS stage, $\mathrm{K}_{c \_ \text {act }}$ was often aligned with that expected under optimal conditions. In contrast, during the MS stage, $\mathrm{K}_{\mathrm{c}_{-} \text {act }}$ was almost always lower than $\mathrm{K}_{\mathrm{c}-\mathrm{mid}}=1.15$ apart after heavy rainfalls. This shows how in non-irrigated conditions, the considerable demand of water of alfalfa at full cover can be unlikely supplied by the soil water storage and precipitation;

- after persistent periods of water scarcity (e.g. last cutting cycles of 2009 and 2010), evapotranspiration moves back to high values if significant rainfalls occur, but this increase could be mainly due to evaporation.

The detected intra and inter-annual variability of $\mathrm{K}_{\mathrm{c} \_ \text {act }}$ makes it opportune to plan other measurement campaigns in order to obtain more information about evapotranspiration dynamics in rainfed crops.

\section{References}

Allen R.G., Pereira L.S., Raes D., Smith M. 1998. Crop evapotranspiration - Guidelines for computing crop water requirements , Irrigation and Drainage Paper56, UN-FA0, Rome, Italy.

Allen R.G., Pereira L.S., Howell T.A., Jensen M.E. 2011 a. Evapotranspiration information reporting: I. Factors governing measurement accuracy. Agric. Water Manage. 98: 899-920.

Allen R.G., Pereira L.S., Howell T.A., Jensen M.E. 2011 b. Evapotranspiration information reporting: II. Recommended documentation. Agric. Water Manage. 98: 921-29. 
Baldocchi D.D. 2003. Assessing the eddy covariance technique for evaluating carbon dioxide exchange rates of ecosystems: past, present and future. Glob. Change Biol. 9:479-492.

Campbell G.S., Norman J.M. 1998. An introduction to environmental biophysics, $2^{\text {nd }}$ ed. Springer, New York.

Doorenbos J., Pruitt W.O. 1977. Guidelines for predicting crop water requirements, Irrigation and Drainage Paper 24 , UN-FAO, Rome, Italy.

Doorenbos J., Kassam A.H. 1986. Yield response to water. Irrigation and drainage Paper 33. UN-FA0, Rome, Italy.

Farahani S.H.J., Howell T.A., Shuttleworth W.J., Bausch W.C. 2007. Evapotranspiration: progress in measurement and modeling in agriculture. Transactions of the ASABE 50: 1627-38.

Foken T., Wichura B. 1996. Tools for quality assessment of surfacebased flux measurements. Agric. For. Meteorol. 78: 83-105.

Foken T., Göckede M., Mauder M., Mahrt L., Amiro B.D., Mauger J.M. 2004. Post-field data quality control. In: Lee X. et al., eds. Handbook of Micrometeorology: a guide for surface flux measurement and analysis. Kluwer, Dodrecht, 181-208.

Foken T. 2008. The energy balance closure problem - An overview. Ecolog. Appl. 18:1351-67.

Foken T., Aubinet, M., Leuning, R., 2011a. The eddy covariance method. In: Aubinet M., et al. eds. Eddy covariance: a practical guide to measurement and data analysis. Springer, Berlin, Heidelberg.

Foken T., Leuning R., Oncley S.P., Mauder M., Aubinet M. 2011b. Corrections and data quality. In: Aubinet M., et al. eds., Eddy covariance: a practical guide to measurement and data analysis. Springer, Berlin, Heidelberg.

Garratt J.R., 1992. The Atmospheric Boundary Layer. Cambridge University Press, New York.

Giorgi F., Lionello P. 2008. Climate change projections for the
Mediterranean region. Global Planet. Change. 63:90-104.

Kljun N., Calanca P., Rotach M.W., et al. 2004. A Simple Parameterisation for Flux footprint Predictions, Boundary-Layer Meteorol. 112: 503-23.

Mauder M., Foken T., Clement R., Elbers J., Eugster W., Grünwald T., Heusinkveld B., Kolle 0. 2008. Quality control of CarboEurope flux data - Part 2: Inter-comparison of eddy-covariance software. Biogeosci. 5:451-62.

Parent A.C., Anctil F. 2012. Quantifying evapotranspiration of a rainfed potato crop in South-eastern Canada using eddy covariance techniques. Agric. Water Manage. 113: 45-56.

Rana G., Katerji N. 2000. Measurement and estimation of actual evapotranspiration in the field under Mediterranean climate: a review. Eur. J. Agron. 13: 125-53.

Reichstein M., et al. 2005. On the separation of net ecosystem exchange into assimilation and ecosystem respiration: review and improved algorithm. Global Change Biol. 11: 1424-39.

Smith M. 2000. The application of climatic data for planning and management of sustainable rainfed and irrigated production. Agric. For. Meteorol.103: 99-108.

Stull R.B. 1988. An introduction to boundary layer meteorology. Atmospheric Science Library, Kluwer Academic Publishers, Dordrecht, Netherlands.

Twine T.E., Kustas W.P., Norman J.M., Cook D.R., Houser P.R., Meyers T.P., Prueger J.H., Starks P.J., Wesely M.L. 2000. Correcting eddycovariance flux understimates over a grassland. Agric. For. Meteorol. 103: 279-300.

Webb E.K., Pearman G.L., Leuning R. 1980. Correction of flux measurements for density effects due to heat and water vapour transfer. Q.J.R. Meteorol. Soc. 106: 85-100. 